\title{
Implementation of Mind Mapp Model Learning in Improving Reading Ability to Read the Qur'an in STMIK Eresha Students South Tangerang City
}

\author{
Yunus $^{1}$ \& Jazuli Mukhtar ${ }^{1}$ \\ ${ }^{1}$ Faculty of Engineering STMIK Eresha Pamulang \\ nurhang542@gmail.com \\ *Corresponding Author: z nurhang542@gmail.com
}

\begin{abstract}
Acquired Data source of that student covers, formative student essay in work problem that is given at the early cycle. Observation sheet result to measure the result step-up studies student with implemented a model of Information proceedings. The study is executed with Classroom Action Research (CAR). This research is executed at STMIK Eresha with the subject of research student total of 53 students. The implementation of the Mind Mapping learning model in the Islamic Religious Education subject is quite good. The results showed that at the first meeting the highest percentage of students who answered could reach $96 \%$. Whereas in the second test, it was $97 \%$ at the $13-15$ meeting. Based on the data, the 13-15 meeting material discussed was the animal excretion system, students felt more difficult with the material than the previous material. The data from the questionnaire results of student responses to the implementation of learning using a learning mind map today can motivate students to learn read the Qur'an. The highest percentage of students who answer can be achieved, reaching $83 \%$ at the $7-9$ th meeting. Most of the students were actively involved in making Mind Mapping. Collaboration is also carried out to make the best Mind Mapping. Student response to the Mind Mapping learning model is also very high. Most of the students felt interested and challenged to make Mind Mapping, although there were a few students who were less happy about the Mind Mapping learning model.
\end{abstract}

Keywords: model; mind mapp; learning; religion education

\section{Introduction}

Educators need to understand the dynamics of change and develop the creativity of educators whose capacity to absorb, adapt, produce or resist renewal itself. Thus, the learning model is an effort to harmonize the development of science and technology into the learning process and at the same time to solve various problems in the learning process, as Nurul Zuriah and Hari Sunaryo argue, "the model in education and learning is an attempt to solve problems in the education sector. and learning.

The quality learning process refers to Law No. 20 of 2003 concerning national education standards Chapter IX article 35 paragraph 1 "National education standards, namely standards of content, process, competence of graduates, educational staff, facilities and infrastructure, management, financing, and educational assessments that must be improved in a planned and periodic manner. This kind oflearning process can only be carried out through learning, namely designing effective learning by considering and using various things optimally, such as choosing a learning model that is in accordance with the characteristics of the subject matter, creating attractive media and utilizing the potential of students so that they can be involved in the learning process (Yunus , 2019). In addition, the quality learning process should also pay attention to the individual conditions of students as unique individuals, and that uniqueness must receive attention in the learning process (Rosciano, 2015).

Students become one of the determinants in considering and implementing appropriate learning models and media according to student characteristics. Thus these components are closely related to realizing the quality of learning.Learning reforms that are being developed in Indonesia, lecturers and teachers are currently being offered a variety of choices of learning models, which sometimes for the benefit of researchers (academic research or action research) it is very difficult to find literary sources. However, if the teachers (prospective teachers) have been able to understand the basic concepts or theories of learning which refer to the learning process (along with concepts and theories) of learning as stated above, then 
basically the teacher can creatively try and develop its own unique learning model, in accordance with the real conditions in their respective workplaces, so that in turn, the teacher's version of learning models will emerge, which of course will further enrich the existing learning models.(Ristiasari, Priyono, \& Sukaesih, 2012)

STMIK Eresha is campus which has students with very diverse characteristics and backgrounds. Students can carry out their religious routines well without any disturbance so that students' religious activities are very thick in their daily lives, for example when the time for dzuhur arrives, students immediately stop their activities and go straight to the mosque, say the call to prayer, give a cult, and become an imam of the prayer, the entire series of worship is carried out by the students themselves, even when they shop for food and drinks in the school canteen, the students themselves calculate the amount of food and beverage bills they consume, so that an honest personality is reflected in the students.

Based on observations, learning to read and write the Koran is currently not showing satisfactory results. Because there are still many problems that cause students to be less enthusiastic about these subjects, including: 1) Inadequate facilities and infrastructure (limited textbooks for students). 2) The learning that is carried out does not attract students' interest so that students get bored easily and students are less active. 3) Low student achievement.

A teacher is able to instill the concept of material well and create a conducive classroom atmosphere, namely a class atmosphere that can inspire students' enthusiasm to follow Islamic Education subjects and be able to improve student learning achievement by using the right learning model when students start to get bored when following the course of the lesson.

For STMIK Eresha students, the application of the Mind Mapp model is very important, because it can improve the intellectual quality of students both from a cognitive aspect. In addition, the use of the Mind Mapp model is expected to have a positive influence on students and be able to improve student learning outcomes. Based on the experiences that researchers face in the inactive learning process of Islamic Education, the researchers try to find other learning models, so that learning is more meaningful and of higher quality.

The application of Mind Mapp is one of the efforts made by educators in an effort to improve student learning outcomes in Islamic Education learning in semester II, the application of Mind Mapp with the aim of improving student learning outcomes in Islamic Education learning is expected to motivate students to be more active in the teaching and learning process. To achieve the expected value according to the specified minimum completeness criteria (KKM).

Improvement and renewal in the world of education is carried out through seminars, workshops, refining curricula, training, which is aimed at teachers or other education personnel regarding learning models and subject matter. However, a problem that continues to occur is that education is teaching that takes place in a monotonous manner so that student boredom occurs in the teaching and learning process. This can be seen when the teacher explains that many students are sleepy, chatting with their friends. The saturation caused by the monotony of the teaching and learning process results in decreased student attention, motivation and interest in the subject matter (Hasibuan, 2000).

Therefore, the model must be selected according to the material to be taught. Because there is no one best model for all materials, the use of models must be adapted to each material. Some use of models that must be adapted to the material in addition to achieving the right goals, also to reduce boredom in students. It should be remembered that Islamic Religious Education exists at all levels from primary to tertiary education. This means that there will be repetitions that lead to boredom. Therefore, the impression that arises later is "underestimating" religious education, because besides the material is only repetitive, the model presented is not attractive. (Fatah Syukur, 2009). PDuring the education process, there is an impression that the learning process does not pay attention to the potential and performance of the brain, even though if it is trained it can emit a light of knowledge in all directions because the brain's neural network continues to form spheres connected by billions of nerves. (Bobbi De Porter, 2009).

Based on the problems above, a thought arose in the minds of researchers to try to offer a new innovation in the teaching and learning process using the Mind Mapp model. Where this model optimizes the potential of the brain in the PBM process. And it is hoped that there will be a new atmosphere in PBM that can focus students on lessons and can improve their learning outcomes.

In accordance with the rationale, the authors are interested in conducting research entitled: "Application of Mind Mapp Learning Model in Improving the Ability to Read and Write the Koran in STMIK students Eresha Pamulang, South Tangerang City ". In addition, it is intended to find out more about the importance of this learning model and it is hoped that the results of the research can be a reference frame for teachers towards achieving good achievement. 


\section{Mind Mapping Model (Mind Map)}

The Mind Mapping method was first introduced by Tony Buzan in the early 1970's. Experts put forward the definition of Mind Mapping as follows:

a. Tony Buzan in his book "The Smart Mind Mapp Book", Mind Mapping is a way of taking notes that are creative, effective and will literally map thoughts. (Tony, 2009).

b. Caroline Edward, Mind Mapping is the most effective and efficient way to enter, store and extract data from or to the brain. This system works according to the natural workings of the brain, so that it can optimize all the potential and capacity of the human brain. (Caroline 2009).

c. Melvin L. Silberman, Mind Mapping is a creative way for individual students to generate ideas, record lessons or plan new research. (Melvin L. Silberman, 2005).

d. Bobby De Porter, Mind Mapping (Mind Mapping) is the use of the whole brain by using Visual Images and other graphics to form an impression between the left brain and the right brain involved so that it makes it easier to enter information into the brain (Bobby De, 2003).

From the above explanation, it can be concluded that the Mind Mapping method is a note-taking technique that can map creative and effective thoughts and integrate and develop the working potential of the brain both in the right hemisphere or the left hemisphere of a person.(Buran \& Filyukov, 2015; Fun \& Maskat, 2010) By using the Mind Mapping method, you can produce notes that provide a lot of information on one page. So with the Mind Mapping method, a long list of information can be transferred into a colorful, highly ordered and easy to remember map that is in tune with the natural workings of the brain.(Adodo, 2013)

Mind Mapping is a form of note that is not monotonous because Mind Mapping combines the work functions of the brain simultaneously and is related to one another. So that there is a balance of work between the two hemispheres of the brain. In general, students make traditional notes in the form of long linear writing that covers the entire content of the subject matter, so that notes look very monotonous and boring. Not only that, students also have difficulty finding the subject matter or points of the subject matter they have learned.(Crowe \& Sheppard, 2012)

Mind Mapping is actually a graphic system involving all the potential of the left brain and right brain. The left hemisphere of the brain has a different function than the right hemisphere. The left brain is the rational brain and the right brain imaginative. The left hemisphere has advantages in logical words, numbers, analysis, and lists and is a short term memory. Meanwhile, the right hemisphere has advantages in rhythm, awareness, imagination, imagining, creativity, color and dimensions as well as long term memory(Iwan Sugiarto, 2004). According to neurologists, quoted by Mustamir Pedak, the key to an intelligent and creative person is to ensure that the left and right hemispheres function optimally and in balance. Although the two hemispheres of the brain have different functions, each individual has a tendency to use one of the dominant hemispheres in solving life problems. Each hemisphere of the brain dominates each other in activity, but both are involved in almost all thought processes (Mustamir, 2009).

Before making a note using the Mind Mapping method. There are several things that need to be considered, among others:
a. Blank paper without lined.
b. Pens and colored pencils.
c. Brain, and
d. Imagination (Tony, 2009).

Mind Mapping is a note-taking method that is different from traditional or conventional notes. A mind map (Mind Mapping) is a technique of recording material to be studied or projecting the problems faced in the form of a map or graphic technique so that it is easier to understand. As forthe differences between regular notes and Mind Mapping notes are as follows:

Table 1. Difference between ordinary and Mind notes Mapping

\begin{tabular}{|c|c|}
\hline Ordinary Notes & Mind Mapping Notes \\
\hline $\begin{array}{l}\text { 1. In the form of writing only. } \\
\text { 2. Only in one color. } \\
\text { 3. To review it took a long time. } \\
\text { 4. The time used for studying is longer. } \\
\text { 5. Static. }\end{array}$ & $\begin{array}{l}\text { 1. In the form of writing, symbols and pictures. } \\
\text { 2. Colorful } \\
\text { 3. A short time was used to review it } \\
\text { 4. The time it takes to } \\
\text { learn faster and more effectively. } \\
\text { 5. Making individuals more } \\
\text { Creative }\end{array}$ \\
\hline
\end{tabular}


Based on the description above, it can also be said that Mind Mapping is a note-taking technique that develops a visual learning style. By integrating a person to organize and remember all forms of information either orally or in writing. With the combination of symbols, colors, and shapes, it will make it easier for the brain to absorb the information it receives compared to using ordinary notes.

\section{Methods}

The purpose of Classroom Action Research according to Suharsimi (2008) is to improve real and practical problems in improving the quality of learning, professionalism, and fostering an academic culture in the classroom that is experienced directly in the interaction between lecturers and students who are studying. (Nana Saodih, 2005)

Meanwhile, the methodology in Classroom Action Research according to Wiriatmadja (2005) is a systematic study of efforts to improve the implementation of educational practices carried out by students by carrying out an act of learning based on existing reflections on the results of research actions. BTQ learning still seems monotonous by using the lecture model only. In this study, there are two subjects that will be subject to classroom action research, and the subjects in the study are as follows: 1) The first subject is STMIK Eresha student. 2) Collaborator or participant, is someone who helps in collecting research data made with researchers. The collaborators in this study were PAI teachers, who taught learning at STMIK Eresha Pamulang. This study uses a qualitative data analysis model flowing from Milles and Huberman in Yuli Eko Siswonwo's Tatag (2008), which includes 3 things, namely: Data reduction (Data display), Drawing conclusions (Conclucion drawing).

There are two criteria used to determine the success of the implementation of learning carried out by researchers in the study, namely: 1) Quantitative indicators, in the form of test scores (values) obtained by students and then compared with the minimum completeness criteria of KKM subjects that have been determined at 75. 2) Qualitative indicators, including student activeness in participating in the BTQ learning process carried out by researchers as well as student attitudes towards learning models developed by researchers comparing the results of interviews and observations. (Burgess-Allen \& Owen-Smith, 2010)

\section{Results and Discussion}

\subsection{Results}

The application of the Mind Mapping learning model received a good response from the majority of students. Students feel happy with the Mind Mapping learning model. They are more active in learning, more enthusiastic and more cheerful than before. The atmosphere in active Mind Mapping learning makes students excited learning. When learning Reading and writing the Qur'an in class, students are no longer sleepy and can participate in learning well. Class atmosphere during Mind Mapping learning Although most students like learning using the Mind Mapping learning model, there are some students who respond poorly to the Mind Mapping learning model.

The student response to the implementation of learning using a mind map?

Student responses to the implementation of the Mind Map use can be seen from the student feedback questionnaire given at the beginning and end of meetings I, II and III. The data from the questionnaire results of student responses to learning using the Mind Map. The first question, whether students can understand the material description given by the lecturer can be seen in Figure 1 below.

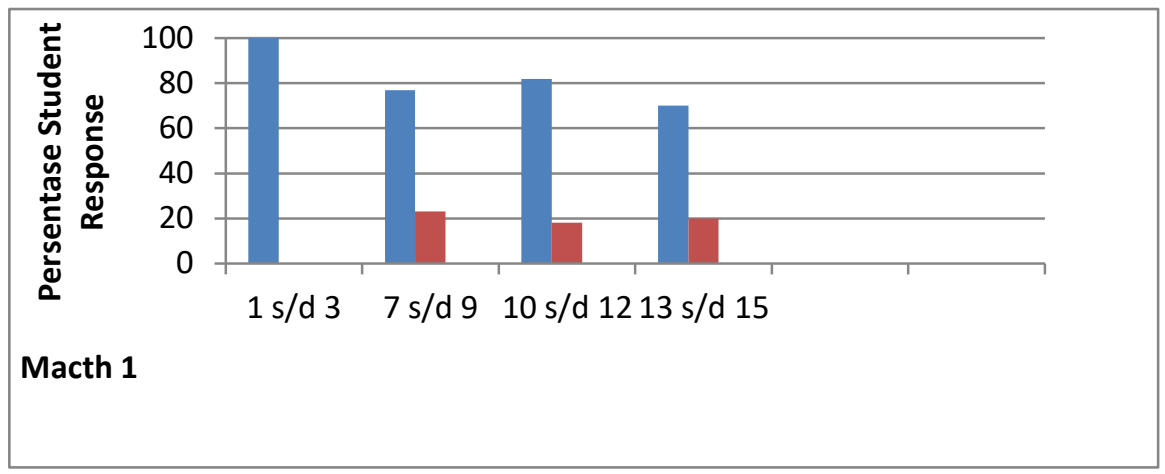

Figure 1: Student Response Graph to Learning Using a Mind Map 
1. Can you understand the material description given by the lecturer?

Based on Figure 1, the results showed that at the first meeting the highest percentage of students answered could reach $100 \%$. This is because students feel the initial material explained by the lecturer is classified as easy to understand, namely about the respiratory organs. At the second meeting the highest percentage of students answered could reach $82 \%$. This value is smaller than in meeting I. This is because at meeting II the material is discussed more complicated for students. The data from the questionnaire results of student responses to the second question, whether students can complete the assigned task properly can be seen in.

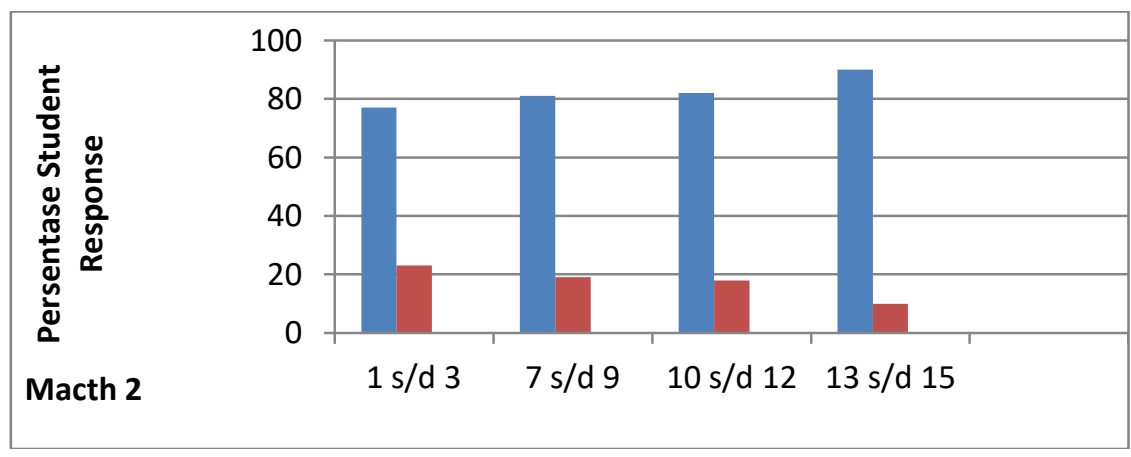

Figure 2: Student Response Graph to Learning Using a Mind Map

2. Question: Can you complete the given assignment or activity well?

Based on Figure 2, the results showed that at the first meeting the highest percentage of students answered could reach $81 \%$. Whereas at the second meeting the highest percentage of students answered yes, reaching $90 \%$. Completion of the task in question is the task of making a Mind Map. At the first meeting students were still not used to making a Mind Map and were still confused about the criteria that had to be considered. The data from the questionnaire results of student responses to the implementation of learning using the Mind Map third question, with the question whether students can understand the work instructions from the lecturer for making a Mind Map can be seen in:

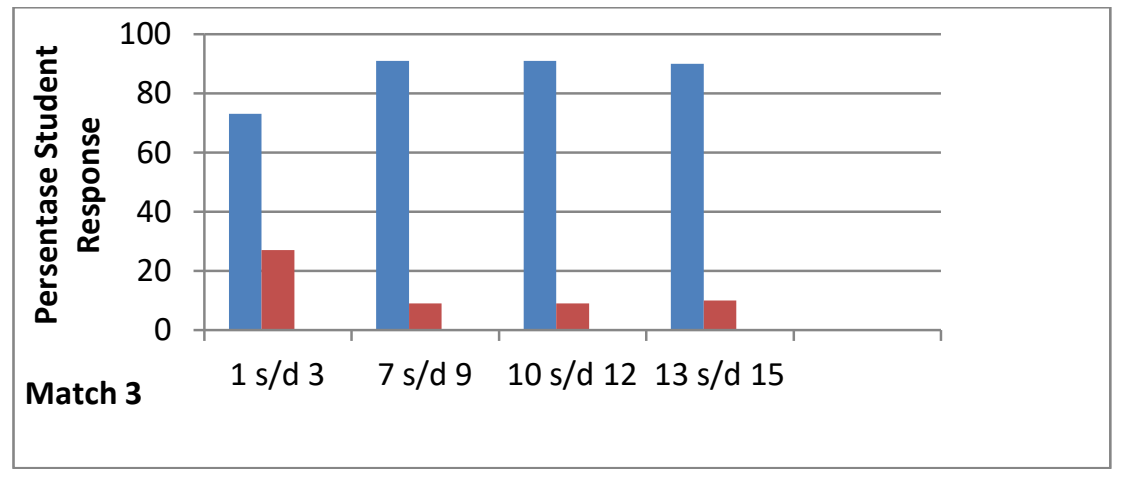

Figure 3: Graph Student Response to Learning Using a Mind Map

3. Can you understand the work instructions from the lecturer when making a Mind Map?

Based on Figure 3, The results showed that in tests I, II, and II the highest percentage of students who answered could reach $91 \%$. Based on the similarity of the percentage values, to find out which meeting the percentage is lower, it can be seen the percentage value at other meetings in the meeting. In the first test, the percentage of answers obtained at the initial meeting reached only $73 \%$, while in tests II and III it reached $90 \%$. Based on these results, it can be seen that the percentage of answers from students on tests II and III is higher when compared to the first test.l earning from each other by having discussions with friends can be seen in. 


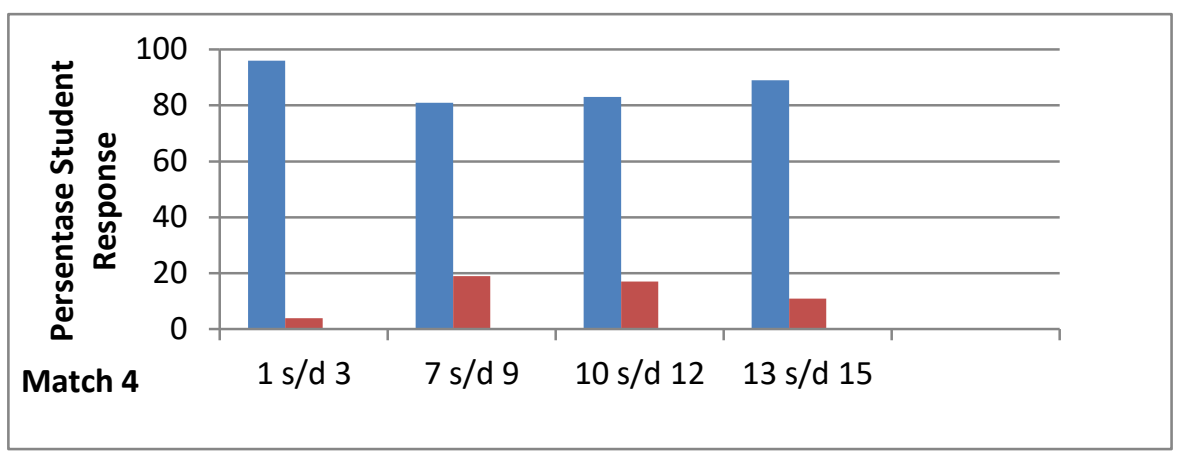

Figure 4: Graph Student Response to Learning Using a Mind Map

4. Can you learn from each other by having discussions with your friends?

Based on Figure 4, the results showed that at the first meeting the highest percentage of students who answered could reach $96 \%$. Whereas in tests II and III it reached $89 \%$. In the first test the results show a greater percentage value when compared to tests II and III. This is because at the first meeting to be precise in the I-III test, the material discussed was about the respiratory organs which students considered easier. The data from the questionnaire results of student responses to the implementation of learning using the Mind Map in the fifth question, with the question whether today's learning can motivate students to learn Reading and writing the Qur'an better can be seen in.

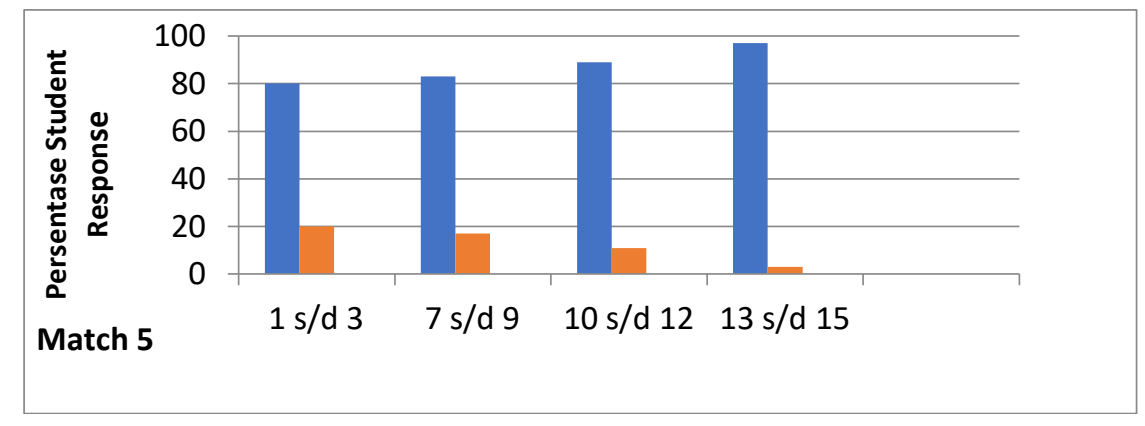

Figure 5: Graph Student Response to Learning Using A Mind Map

\section{Can today's learning give you motivation to learn}

Reading and writing the Qur'an even better?

Based on Figure 5, the results show that in the first test the highest percentage of students who answered could reach $83 \%$ at the 7-9th meeting. Whereas in the second test, it was $97 \%$ at the 13-15 meeting. Based on the data, the 13-15 meeting material discussed was the animal excretion system, students felt more difficult with the material than the previous material.

\subsection{Discussion}

At the first meeting, the lecturer explains what is meant by a mind map by telling the functions and uses as well as the advantages if we learn to use a mind map. The lecturer gave an example of how to make a simple mind map. The lecturer explains the material elements of hijaiyah letters and the importance of the environment by using a mind map. The lecturer asks students to try to make a mind map regarding the material that has been explained guided by the lecturer. One student was asked to draw the mind map in front of the class. The lecturer concludes the material at the end of the meeting. In the closing session, the lecturer gave the assignment, namely dividing students into ten groups and each group consisting of four people and distributing two learning texts containing material reading forms.

The group was tasked with making a mind map for the material in text two. This material is discussed at the next meeting. At the second meeting, the implementation of learning using the mind map learning method is as follows. Lecturers make apperception to find out the extent of understanding of the previous material. The material taught is the Idgham reading form. Students position themselves or sit with members of their respective groups. The lecturer checks the assignments that have been made by the students. Students discuss for several minutes with their groups. Representatives of each group come forward to write in front of the class the mind map that has been made for discussion together. The other groups take turns 
completing the mind map that has been written in front of the class and so on until the mind map is perfect and can describe and explain all the material available. Students are also given the opportunity to ask questions about the mind maps that have been written in advance. Students who had written their mind maps in front were also given the opportunity to answer questions about what they had written in front. The lecturer explains sequentially the material by using a mind map that has been made by the student in front of the class and completes it.

The lecturer gives assignments to students at the end of the meeting and shares the third learning text which contains material about the nature of sustainable development and the characteristics of sustainable development.(Parikh, 2016; Spector, 2020) The task is to make a mind map for the next material individually. So students are asked to make a mind map with their own abilities. The meeting of the two students was still taught using mind maps. The lecturer performs apperception to find out the extent of the absorption of the material that has been taught. Lecturers check individual assignments assigned to students. The lecturer asks several students to write a mind map to the front of the class. Other students are allowed to complete the mind map in front. Students are allowed to ask questions about the mind map that has been made in advance. Students are allowed to answer the mind maps that they have made.(Brinkmann, 2003) The lecturer explains the material using mind maps that have been made by students and completes the mind maps that have been made by students. The lecturer concludes the material that has been explained.

The lecturer provides the opportunity to ask questions if it is not clear what the lecturer explains. The lecturer assigns assignments to students individually at the end of the meeting. The task is to make a mind map to understand all the material from beginning to end. The fourth meeting or the last meeting is an evaluation or posttest. The lecturer checks the assignments that students have made and collects them. Lecturers invite students to ask questions. After the questions from students are answered, it is immediately carried out. This aims to determine the extent to which students master the material that has been taught.

Mind Mapping also requires courage and high creativity. Variations with capital letters, colors, underlines or symbols that illustrate the main point or idea. Bringing the Mind Mapping to life will be even more impressive. The assumptions underlying the theories of the mind mapping model explain (1) the nature of the human memory system, and (2) the way in which knowledge is described and stored in memory. The old conception of human memory is that memory is merely a storage place to store information for a long time, so that memory is defined as a collection of small pieces of information that are detached or have nothing to do with each other. The process of information in memory begins with the process of encoding the information (encoding), followed by information storage (stroge) and ends by revealing the information that has been stored in memory (retrival). Information processing learning theory describes the act of learning as an internal process that includes several stages.

Encodingis the process of entering information into memory. The nervous system uses an internal code that represents an external stimulus. In this way the external object/event representation is coded into internal information and ready to be stored. Strogeis information taken from short-term memory and then forwarded to be processed and combined into long-term memory. However, not all information from shortterm memory can be stored. The key to the storage in long-term memory is sufficient motivation to encourage repeated practice of things from short-term memory. Retrievalis the end result of the memory process. Refers to the utilization of stored information. In order to be retrieved, the stored information is not only available but also obtainable because although theoretically the stored information is available it is not always easy to use and place it. There are several stages that must be done in the cognitive growth learning model, namely:

\section{Orientation stage}

At this stage the lecturer conditions students in a position ready to carry out learning. The orientation stage is carried out by, first, an explanation of the objectives that must be achieved, both goals related to mastery of the subject matter that must be achieved, as well as goals related to the learning process or thinking abilities that students must have. Second, an explanation of the learning process that students must do, namely an explanation of what students must do at each stage of the learning process.

\section{Tracking stage}

The tracking stage is the exploratory stage to understand the experiences and basic abilities of students according to the theme or subject matter to be discussed. Through this stage the lecturer develops dialogue and questions and answers to reveal what experiences students have that are considered relevant to the theme to be studied.

\section{The confrontation stage}

The confrontation stage is the stage of presenting problems that must be solved according to the level of ability and experience of students. To stimulate an increase in student ability at this stage the lecturer can provide dilemma problems that require answers or solutions. At this stage the lecturer must be able to develop a dialogue so that students really understand the problems that must be solved. 


\section{Inquiry stage}

At this stage, students learn to think in real terms. Through the inkuri stage, students are invited to solve the problems they are facing. At this stage the lecturer must provide space and opportunity to develop ideas in problem solving efforts. Through various questioning techniques, the lecturer must be able to foster the courage of students so that they can explain, reveal facts according to their experiences, provide convincing arguments, develop ideas and so on.

\section{The accommodation stage}

The accommodation stage is the stage of forming new knowledge through the inference process. At this stage students are required to be able to find key words according to the topic or theme of learning. At this stage, through dialogue, the lecturer guides students to conclude what they have found and understand about the topic in question.

\section{Transfer stage}

The transfer stage is the stage of presenting a new problem that is commensurate with the problem presented. The transfer stage is intended as a stage so that students are able to transfer the thinking skills of each student to solve new problems. At this stage the lecturer can provide assignments that are in accordance with the topic of discussion.

Mind Mapping (Mind maps) are a note-taking model that develops a visual learning style. The combination of colors, symbols, shapes and so on makes it easier for the brain to absorb the information it receives. The Mind Mapping learning model is a learning model based on constructivism theory. The constructivist approach to learning implements cooperative learning intensively, on the basis of the theory that students will find it easier to find and understand difficult concepts if they can discuss these problems with their friends. (Trianto, 2007). As when students study in groups to make Mind Mapping, when there is one student who finds it difficult to understand the concept of the subject matter that will be made by Mind Mapping, he will ask his friends in one group about what the concept actually means, so that he will there was an exchange of opinion and finally found a solution. So, with the Mind Mapping learning model, students will find it easier to understand the subject matter because they can work together with their group friends and discuss the difficulties encountered so that they get solutions. The Mind Mapping learning model, which is a learning model based on constructivist theory, is a learning model that combines ideas, words, symbols, pictures, or other graphics. This learning model can develop students' right and left brain activity. This learning model is very suitable to be applied to PAI Education subjects, where most of the material is memorization which requires a strong memory and understanding of the subject matter of Islamic Religious Education.

One of the benefits of Mind Mapping is that it makes it easier to learn on subject matter that demands a high level of memorization and also says that Mind Mapping is a creative note-taking model that makes it easier for us to remember a lot of information. Mind Mapping is a model for expressing ideas in a visually appealing way and applying the two brain functions synergistically. Therefore Mind Mapping is very suitable for use in Islamic Eduation subjects specifically for Reading and writing the Qur'an material. When students make a Mind Mapping, the student's right and left brain functions in balance, this is because when students read about the Citizenship Education subject matter, they will think about the Citizenship Education material and finally understand it, find the key words and put them in writing, at the time that is the student's left brain works. However, when students imagine to determine symbols or pictures related to the subject matter to be made in their Mind Mapping, then the right brain works at that time. So, it is with the activity of the two halves of the student's brain that the student will finally understand quickly and easily remember the subject matter they are learning.

In addition, the Mind Mapping learning model is a learning model that involves two student activities, namely psychological and physical activities. Student psychic activity is when students make Mind Maps, the students' minds will function because they think to find ideas. Meanwhile, the physical activity of students is that students make the Mind Mapping and provide color, image and graphic symbols. If the lecturer class provides opportunities for students to learn through these two activities, students will learn and think optimally. This agrees with Ahmad who said that a child thinks as long as he does. Without doing, children do not think, so that they think for themselves (actively) they must be given the opportunity to do things themselves. Thinking at the verbal level only arises after the individual thinks at the action level, here the principle of learning by doing-learning by experience applies. Therefore, with the Mind Mapping learning model, student activity can increase. The Mind Mapping learning model is very effective in increasing student involvement in the learning process. The impact of the increased activity causes the growth of individual skills, social skills and emotional abilities of students. This fact is shown by the ability of students to be active in listening to lecturers' explanations and reading subject matter, answering questions from lecturers and friends or other groups, having the courage to defend opinions or refute opinions when discussing and presenting their work, having a sense of responsibility to themselves and to 
groups. . Students are also able to show mutual respect between fellow group members and other group members.

The increase in student activity is because in the Mind Mapping learning model, emotional bonds are established between students and lecturers. When students learn, it does not only involve IQ but also emotions, so that it can guide student decisions over time. This is like the opinion of Bobbi de Porter who said that in living and learning a person does not only involve IQ but also involves emotions, atmosphere and thoughts (emotional power). When learning Mind Mapping, students and lecturers' emotions can be more stable and happy. From this description, it can be concluded that student activities will be maximized if students study in a pleasant learning atmosphere or environment, students can gain direct experience in learning through reading, listening, seeing, and also listening. In addition, student learning outcomes can also improve if students are able to use both hemispheres of the brain (right brain and left brain) synergistically. so that students have high memory in remembering the subject matter.

The student response to the application of the mind is very liked by most of the students, this can be seen that the students are very enthusiastic in following the lesson, more happy and excited. Learning conditions seem more interesting and fun, students are no longer the object of learning but as the subject of learning. Many students feel that the 2 lesson hours available in the learning process are very short because they are busy making Mind Maps. Most students are involved in learning activities and have the same responsibility in the group. Although the Mind Mapping learning model received good responses from the majority of students, there were a few or some students who did not like the Mind Mapping learning model. This is because they don't like making pictures or symbols so they don't like making Mind Maps.

The use of Mind Mapping is an activity to represent ideas expressed by a discourse by using all graphic symbols in one map image. Graphic symbols are words, images, numbers, distances, colors, symbols etc. The best mind map is a mind map that uses a lot of pictures and symbols, so it takes a lot of creativity in making a Mind Mapping. However, in practice, there are still some students who are less creative in making Mind Mapping. They still have difficulty in making symbols and pictures that are right for their Mind Mapping topic. Lecturers as much as possible accustom students to think and do creative things so that students can quickly develop their creativity. The time allocation for Islamic Education subjects which is only two hours of lessons causes the implementation of learning in class to be less than optimal. Lack of time allocation for Islamic Education Lecture in delivering learning information and in implementing the Mind Mapping learning model makes the subject matter less conveyed optimally. The time allocation is not free to carry out more creative, innovative and fun learning, it is feared that the material cannot be delivered completely. Therefore, the best use of time must be carried out by lecturer and students alike.

\section{Conclusion}

The implementation of the Mind Mapping learning model in the Islamic Religious Education subject is quite good, the lecturer prepares before carrying out the Mind Mapping learning model by making a learning implementation plan, the teacher applies the Mind Mapping learning model by guiding and providing direction to students at the time. Students make Mind Maps and presentations, and accompany students during discussions and questions and answers. Mind Mapping learning model, namely the increase in student learning activities in expressing opinions, the courage to ask questions, student enthusiasm and student cooperation in completing their learning assignments. In addition, by being able to make Mind Maps, Students can also apply the Mind Mapping model to help solve problems encountered in students' daily lives. The Mind Mapping produced by the students is quite good. Student responses to the Mind Mapping learning model were very high. Most of the students felt interested and challenged to make Mind Mapping, even though there were some students who were less happy with the Mind Mapping learning model.

\section{References}

Adodo, S. O. (2013). Effect of mind-mapping as a self-regulated learning strategy on students' achievement in basic science and technology. Mediterranean Journal of Social Sciences, 4(6), 163-172. https://doi.org/10.5901/mjss.2013.v4n6p163

Arikunto, Suharsimi, dkk. (2008) Penelitian Tindakan Kelas, Jakarta: Bumi Aksara, pp.60.

Brinkmann, A. (2003). Graphical Knowledge Display: Mind Mapping and Concept Mapping as Efficient Tools in Mathematics Education. Mathematics Education Review, (16), 35-48.

Bobby De Porter, Mike Hernacki, (2003) Quantum Learning, Membiasakan Belajar yang Nyaman dan Menyenangkan, Bandung: Kaifa,

Bobby De Porter, Mike Hernacki, (2010), Quantum Learning, Bandung: Kaifa.

Buran, A., \& Filyukov, A. (2015). Mind Mapping Technique in Language Learning. Procedia - Social and 
Behavioral Sciences, 206(November), 215-218. https://doi.org/10.1016/j.sbspro.2015.10.010

Burgess-Allen, J., \& Owen-Smith, V. (2010). Using mind mapping techniques for rapid qualitative data analysis in public participation processes. Health Expectations, 13(4), 406-415. https://doi.org/10.1111/j.1369-7625.2010.00594.x

Buzan, Tony, (2009), Buku Pintar Mind Mapp, Jakarta: Gramedia Pustaka Utama.

Crowe, M., \& Sheppard, L. (2012). Mind mapping research methods. Quality and Quantity, 46(5), 1493-1504. https:// doi.org/10.1007/s11135-011-9463-8

Davies, M. (2011). Concept mapping, mind mapping and argument mapping: what are the differences and do they matter?. High Educ 62, 279-301. https://doi.org/10.1007/s10734-010-9387-6

Edward, Caroline, (2009) Mind Mapping untuk Anak Sehat dan Cerdas, Yogyakarta: Sakti,

Fun, C. S., \& Maskat, N. (2010). Teacher-Centered Mind Mapping vs Student-Centered Mind Mapping in the teaching of accounting at Pre-U level- An action research. Procedia - Social and Behavioral Sciences, 7(2), 240-246. https://doi.org/10.1016/j.sbspro.2010.10.034

Hasibuan dan Moedjiono, (2000), Proses Belajar Mengajar, Bandung: PT Remaja Rosdakarya.

L. Silberman, Melvin, (2005), Active Learning: 101 Strategi Pembelajaran Aktif, Yogyakarta: Yappendis,

Mento, A.J., Martinelli, P. and ذones, R.M. (1999), "Mind mapping in executive education: applications and outcomes", Iournal of Management Development, Vol. 18 No. 4, pp. 390416. https:// doi.org/10.1108/02621719910265577

Parikh, N. D. (2016). Effectiveness of Teaching through Mind Mapping Technique. The International Journal of Indian Psychology, 3(3), 148-156.

Ristiasari, T., Priyono, B., \& Sukaesih, S. (2012). Model Pembelajaran Problem Solving Dengan Mind Mapping Terhadap Kemampuan Berpikir Kritis Siswa. Journal of Biology Education, 1(3).

Rohani, Ahmad, (2004), Pengelolaan Pengajaran, Jakarta: Asdi Mahasatya.

Rosciano, A. (2015). The effectiveness of mind mapping as an active learning strategy among associate degree nursing students. Teaching and Learning in Nursing, 10(2), 93-99. https://doi.org/10.1016/j.teln.2015.01.003

Spector, J. M. (2020). Learning, Design, and Technology. Learning, Design, and Technology. https://doi.org/10.1007/978-3-319-17727-4

Sugiarto, Iwan, (2004), Mengoptimalkan Daya Kerja Otak Dengan Berfikir Holistik dan Kreatif, Jakarta: Gramedia. Syukur, Fatah, (2009), Metodik Khusus Pendidikan Agama Islam, Semarang: Akfi Media.

Saodih Sukmadinata, Nana, (2005), Metode Penelitian Pendidikan, Bandung: Remaja Rosdakarya,

Tatag Yuli Eko Siswono. (2008). Mengajar \& Meneliti, Surabaya: Unesa University Press, pp. 29.

Trianto, (2007), Model-model Pembelajaran Inovatif Berorientasi Konstruktivistik, Jakarta: Prestasi Pustaka.

Wiriatmadja, Rokhiyati. (2005). Metode Penelitian Tindakan Kelas, Bandung: Remaja Rosdakarya, pp. 12

Yunus, Y., Suardi, D. (2019). Al-Quran Learning Through Information Processing Model Ala Joyce and Weil MTs Works in The Village Lara Mulya Baebunta District District North Luwu. International Journal for Educational and Vocational Studies, 1 (2), 104-108.

Yunus, Y. (2020, October 9). Kearifan Lokal Budaya Bugis Dan Pluralisme (Studi Pendidikan Karakter pada Perguruan Tinggi di Kota Palopo Tahun 2017-2020). https:// doi.org/10.17605/OSF.IO/WXTN3.

Zuriah, Nurul dan Hari Sunaryo, (2009), Inovasi Model Pembelajaran Berperspektif Gender, Teori dan Aplikasinya di Sekolah, Malang: UMM Press. 